\title{
THE SEPERATION OF POWER: AN EXPERIMENT OF THEORY AND PRACTICE Gopal Prasad Dahal*
}

\begin{abstract}
When the legislative and executive power united in the same person, or in the same body of magistrates, there can be no liberty... Again, there is no liberty if the power of judging is not seperated from the legislative and executive. If it were joined with the legislative, the life and liberty of the subject would be exposed to arbitrary control; for the judge would then be the legilsatior. If the were joined to the excutive power, the judge might behave with vioence and oppression. There would be an end to everything, if the same man or the same $b$ ody, whether of the nobles or the people, where to exercise those three powers, that of enacting laws, that of executing public affairs, and that of trying crimes or individual causes. (Baron Montsquieu, 1989-1755).
\end{abstract}

\section{INTRODUCTION}

The separation of powers, together with the rule of law and parliamentary sovereignty, runs like a thread throughout the constitution of the Nepal. It is a doctrine which is fundamental to the organisation of a state government and to the concept of constitutionalism- in so far as it prescribes the appropriate allocation of powers, and the limits of those powers, to differing instituions. The concept has played a major role in the formaiton of constitutions. The extent to which powers can be, and should be, separate and distinct was a central feature in formulating, for example, both the American and Frence revolutionaary constituitons. In any state, three essential bodies exist: "the executive, the legislature and the judiciary." It is the relationship between these bodies which must be evaluated against the backcloth of the principle. The essence fo the docrine is that there should be, ideally, a clear demarcation of functions between the legislatuve, executive and judiciary in order that none should have excessive power and that there should be in place a system of "checks and balances" between the instituions. However, as will be seen, there are significant departures from the pure doctrine under the Nepalese constitution, and it must be conceded that, while the doctrine is accorded respect, it is by no means absolute.

The seperation of power means destribution of power. If has may be employed two methods for the distributing government power. First, territorial (division of federalism) distribution and second is funcitonal distribution. These two are not alternative method. The territorial division is related of the torritory of the state into political division. The funcitonal division is which it preforms, its function. But the work of governemt is so wide and complex that it is imperative to establish special organ for the performance of the several kinds of work to be done. When the work of government is distributed to political organs in accordance with the nature of function to be performed, it is the functional distribution powers.

Dr. Dahal is an Associate Proffessor, Nepal Law Campus, T.U., Kathmandu, Nepal. 
Based upon this principle of distribution, all the power of government have long been coceived as falling with one or another of three great classes. First the enactment of making of law. Second, the interpretaiton of these law and Third, their enforcement of laws. These three classes have been given the names, legislative, executive and judicial. These structurally considered, governement have been demand to be made up of three branches having for their function the exactment, the adjudicaiton, and the enforcement of law. These function belong are known as the legislative, the judiciary, and the executive respectively.

\title{
MEANING AND DEVELOPMENT
}

First of all, the identification of the three elements of the constituion derives from Aristotle (384-322BC). In "The Politics," Aristotle proclaimed that:

\begin{abstract}
There are three elements in each constituion in respect of which every serious lawgiver must look for what is advantageous to it; if these are well arranged, the constitution is bound to be welll arraned, and the differences in constitutions are bound to correspond to the differences between each of these elements. The three are first, the deliberative, which discuss everything common importance; second, the officials; and third, the judicial element.
\end{abstract}

The constitutional seeds of the doctrine were thus sown early, reflecting the need for governemt according to and under the law, a requriement encouraged by some degree of a separation of functions between the instituiions of the state. The constituional historian FW Maitlad traces the separation of powers in England to the reign of Edward I 1272-1307, "In Edward's day all becomes definite - there is the Parliament of the three estates, there is the King's Council, there are the well known courts of law" (1908: 20).

Viscount Henry St. John Bolingbroke (1678-1751), in "Remarks on the History of England," advanced the idea of separation of powers. Bolingbroke was concerned with the necessary balance of powers within a constitution, arguing that the protection of liberty and security within the state depended upon achieving and maintaining an equlibrium between the Crown, parliament and the people. Addresing the respective pwoers of the King and parliament, Bolingbroke observed that:

Since this division of power, and these different privileges constitute and maintain our government, it follows that the confusion of them tends to destroy it. This propositon is therefore true that, in a constituion like ours, the safety of the whole depends on the balance of the parts (1748: 80-83).

Montesquieu baron in France 1689-1755, living in England from 172931, stressed the importance of the judiciary in "De l'Esprit des Lois" (1748):

When the legislative and executive powers are united in the same person, or in the same body of magistrates, there can be no libery... Again, there is no liberty if the power of judging is not separated from the legislative and executive, If it were joined with the legislative, the life and liberty of the subject would be exposed to arbitary control, for the judge would then be the legislator. If it were joined to the executive power, the judge might behave with violence and oppression. There would be an end to everything, if the same man, or the same body, whether of the nobles or the people, were to exercise those three powers, that of enacting laws, that of exeuting public affairs, and that of trying crimes or individual causes. 
Here is the clearest expression of the demand for a separation of funcitons. It has been remarked that Montesquieu's observations on the English constituion were inaccurate at the time representing more a description of an idealised state than reality (Vile, 1967: 84-85). Moreover, if should not be assumed that Montesquieu's preferred arrangement of a pure separation of powers is uncontrovesial. Throughout history, there has been exhibited a tension between the doctrine of sepearion of powers and the need for balanced government- an arrangement depending more on 'checks and balances' within the system (as emphasised by Bolingbroke) than on a formalistic separation of powers. Sir Ivor Jennings has interpreted Montesquieu's words to mean not that the legislature and the executive should have no influence over the other, but rather that neither should exercise the power of the other (Jennogs, 1959 of Appendix 1) Sir Willam Blackstone (1765: 69) a discipe of Montesquieu, adopted and adapted Montesquieu's strict doctrine, reworking his central idea to incorporate the theory of mixed government. While it was of central importance to Blackstone that, for example, the exeutive and legislature should be sufficiently separate to avoid 'tyranny', he nvertheless viewed their total separation as potentially leading to dominance of the executive by the legislature. Thus, partial separation of powers is required to achieve a mixed and balanced constitutional structure.

\section{THEORY}

Political Liberty, we have emphasised, is possible political. only when the government is restrained and limited. The theory that the funcitons of government should be differentiated and that they should be performed by distinct organs consisting of different bodies of persons, so that each department should be limited to its own sphere of acting without encroaching upon the others, and that it should be independent with the sphere, is called the theory of the seperation of powers.

Monteguieu, wrote in his famous book "The sprite of the Law that" constant experience shows us that every man invested with power is apt to abuse it, and to carry his authority until he is confroted with limits." He assarts that concetrated power is dangerious and leades to despotism. But how to avoied concentration of power? His answer is simple: by seperating the functions of the executive, legislative and judicial departments of government, to that one may operate as a balance against anotehr and, thus power should be check on power.

The separation of powers doctrine does not insist that there should be three instituions of government each opeating in isolaiton from each other. Indeed, such an arrangement would be unworkable, particularly under a constitution dominated by the sovereignty of parliament. Under such an arrangement, it is essential that there be a sufficient interplay between each institution of the state. For example, it is for the executive, for the most part, to propose legislation for parliament's approval. Once passed into law, Acts of Parliament are upheld by the judiciary. A complete separation of the three institutions could result in legal and constitutional deadlock. Rather than a pure separation of powers, the concept insists that the primary functions of the state should be allocated clearly and that thre should be 
checks to ensure that no institution encroaches significantly upon the function of the other. If hypothetical constitutiional arrangements within a state are considered, a range of possibilities exists.

(1) absolute power residing in one person or body exercising exeutive, legislative and judicial powers: no separation of powers;

(2) power being diffused between three separate bodies exercising separate functions with no overlaps in function or personnel: pure separation of powers; and

(3) powers and personnel being largely- but not totally- separated with checks and balances in the system to prevent abuse: mixed government and weak separation of powers.

It is to this third category that the constitution of the Nepal most clearly subscribes.

\section{THREE ORGANS OF THE GOVERNMENT}

\section{THE EXECUTIVE}

The exeutive may be defined as that branch of the state which formulates policy and is responsible for its execution. In formal terms, the soverein is the head of the executive. The Prime Minister, Cabinet and other ministers for the most part, are elected Mmbers of Parliament. But in the context of Nepal, at that time there is no Parliament. Chief Justice of Supreme Court are appointment in the post of cabinate chairman and other retire civil service secarity are appointed in the cabinate ministry. In addition, the Civil Service, local authoritities, police and armed forces, constitute the exeutive in practical terms.

\section{THE LEGISLATURE}

The Parliament is the sovereign law making body. Formally expressed, all bills must be passed by Parliament. Parliament is bicameral, that is to say there are two chambers, each exercising a legislative role- although not having equal powers- and each playing a part in ensuring the accountability of the government. By way of introduction, it should be noted that membership of the Parliament is not secured by election and is accordingly not accountable in any direct sense to the electorate. Directly elected, and a Parliamentary term is limited under the Parliament Act to a maximum of five years. In practice, the average life of a Parliament is between three and four years. The House is made up of the majority party: the political party which secres the highest number seats at the election. Which will form the government. But at that time here is no elected body legislative in Nepal. The official Opposition is the party which represents the second largest party of elected members. In principle, the role of the official Opposition is to act as a government is waiting, ready at any time to take office should the government seek a dissolution. But in the context of Nepal opposition party also nil.

\section{THE JUDICIARY}

The Judiciary is that branch of the state which adjudicates upon conflicts between state institutions, between state and individual, and between individuals. 
The Judiciary is independent of both parliament and the executive. It is the feature of judicial independence which is of prime importance both in relation to government according to law and in the protection of liberty of the citizen against he executive. As Blackstone observed in his "Commentaries." (Vol. I: 204)

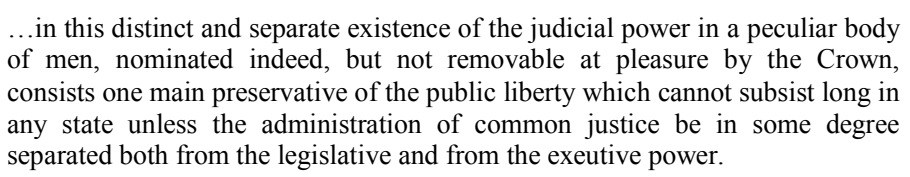

It is apparent, however, that, whilst a high degree of judicial independence is secured under the constitution, there are several aspects of the judicial function which reveal an overlap between the judiciary, parliament and the executive.

\section{POWER HALTS POWER (LE POUVAIR ARRETE LE POUVAIR)}

A constitution may be such that non "shall be compelled to do thing to which be is not obliged by law, or not to do things which the law permits." This thesis is the division of power by function and the theory emerging therefrom is known as that of the seperation of powers.

This idea contained in the theory of the seperation of powers was not entirely known before Monlesfuieu. Its origin can be traced back to Aristotle; In the solities is found an analysis of three 'parts', or branches of government, but he did not go into details. Various political philosophers, in the fourteenth century, gave some attntion to the theory of seperation of powers, but it meant little to political science until the issue of political liberty became urgent. In the $17^{\text {th }}$ century it "began to acquire meaning, and in the $18^{\text {th }}$, which critical times, it came to the forefront of discussion." The seperation of power show's that if the legislative and executive power are combined in the same person or body of person or body of person, there can be no libery, because the same agency becomes the maker and execuior of laws.

Similarly, if the legislative and judicial functions are combined with the judicial, the same agency in the prosecutor as will as the Judge. If all the three power are concentrated in a single hand tehre should be an end of everything, as there will be tyrannical laws interpreted and enforced with the violence of an oppressor.

Montesguieue's thesis is that concentration of legislative, executive and judicial functions. Either in one single person or a body of persons, reasults in abus of authority and such an organisation is tyrannicla. He urg that the three departments of governement should be so orgainsed that each should be entrusted to different person and each department should preform distinct funcitons within the sphere of powers assinged to it.

\section{APPLICATION}

Nepal.

This theory has had different application in France, U.S.A., India and

\section{FRANCE}

It resulted in the rejection of the power of the courts to review acts of the legislature. The existence of separate administrative courts to adjudicate disputes 
between the citizen and the administration owes its origin to the theory of separtion of power.

\section{AMERICA}

America change this principle was categorically adopted in the making of the "Constitution of the United States of the America." There, the executive power is vested in the President (Article II Sec. I), the legislative power in Congress (Article I, Sec I) and the judicial power in the Supreme Court and the courts subordinate there to (Article III, sec. I). "The president is nto a member of the congress." His secretaries are appointed by him on the basis not of their party loyalty but loyalty to himself. His tunure does not depend upon the confidence of the Congress in him. "He cannot be removed except by impeachment." However, the United States' Constitution makes departure form the theory of strict separation of powers in this that there is povision for judicial review.

\section{INDIA}

"In India, the executive is part of the legislature." The President is the head of the executive but he acts on the advice of the Council of "Ministers" (Article 53 and 744 of The Indian constitution). "He can be impeached by Parliament." The Council of Ministers is collectively responsible to the Lok Sabha and is therefore removable by it (Article 753). There is separation only so far as the judiciary and other organs of the government are concerned (Article 124(i). "The judges of the superior courts are appointed by the government (Article 124(2) and 217(1)), although they can be removed only by Parliament" (Article 124(2) praviro (2) and their salaries are provided by the Constitution or can be laid down by a law made by Parliament (Article 125 and 221). The courts can declare legislative as well as executive acts unconstitutional (A.K. Gopalan vs. Madras AIR 1950, SC 27).

Functionally the President's or Governor's assent is required for all legislaitons (Aritcle III, 200 and 368). The Preseidnet or the Governor has powr making ordinances when both Houses of the legislature are not in session (Aritcle 123 and 219). This is legislative power, an ordinance has the same status as a law of the respective legislature (A.K. Roy vs Union of India AIR 1982 SC 710). The President or the Governor has the power to grant pardon (Aritcle 72 and 161). The legislature performs judical funciton while committing for contempt those who defy its orders or commit breach of privilege (Aritcle 105(3), and 194(3)). The Supreme Court has power of making rules (Aritcle 145). It can punish for contempt (Aritcle 129). The High Courts have administrative control over courts subordinate there to (Aritcle 227).

This does not mean that the principle of separation of power is "altogether discarded." Except where the Constituiton has vested power in a body, as for example, the ordinance making power vested in the President or the Governor, the principle that one organ should not reform functons of the other is followed. As was stated in "Ram Jawaya vs. Punjab by the Supreme Courst" (AIR 1955 SC 549, 556).

The Indian Constitution has not indeed recognised the doctrine of separation of powers in its abolute rigidity but the functions of the different parts or branches 
of the Government have been sufficiently differentialted and consequently it can very well be said that our Constitution does not contemplate assumption, by one organ or part of the State, of funcitons that essentially belong to another.

The system that operates in India is like England, 'of checks and balances.' Therefore, when Parliament sought to obliterate a judicial decision in which eleciton of the Prime Minister to the Parliament had been set aside by passing a constitutional amendment, the Supreme Court (Ray C.J., Beg, Mathew, Chandrachud and Khanna JJ.) in "India Gandhi vs. Raj Narayan" (AIR 1975 SC 2299) held that it was not a constitutional amendment at all since judicial decision could not be "overturned by legislative process." In administrative process we often see a comobination of all the three funcitons in a single agency, i.e. in an administrative authority but administrative law makes distinction in the method of exercise of each of such functions. "Barring the Ordinacne making power (Article 123) and other Rule making powers of the President" (Article 309) and similar powers conferred on the Governor (Article 213), "Administrator of a Union Territory (Article 279B) by the Constitution," the executive cannot perform essential legislative funciton. "Similarly, the legislature does not perform essentially executive or judicial functions." Although the executive authorities perform judicial functions, they are called quasi-judicial and ultimately the exercise of such functions by the executive is subject to the control of the ordinary courts. Unlike in France, where administrative courts are subject to the appellate jurisdiction of the highest administrative court (Conseil d'Etat), the administrative tribunals in India, like England, are not subject to any highest administrative court but are subject to the appellate as well as review jurisdiction of the Supreme Court.

NePAL

The vision of tyranny rule has been avoided in Nepal by adoption of the following schem:

(1) The executive which formulates policy, executes it, and governs the country in accordance with article 37(2) consist of elected and some nominated members of Parliament, who are under the controle of Parlaiment.

(2) The executive which controls the national purse is itself. Controlled in its use of finance by Parliament and is scrutionised by the Auditor General.

(3) The Parliament which exercised general legislative powers is made up of the people's representatives, but is motivated most of the time, by the programmes of the executive under Part 5 (Article, 37,38,39, 40,41, 42, 43 and 44).

(4) The exeutive is remin in power but the executive can dissolved the legislative Parliament if it find that the house is not respecting its activities.

(5) All three major organs of the state- the executive the legislative and the judiciary are distinct branches of the system of government, but the 
executive and legislature must work together in the context of a proper relationship, if the country is to be proverly governed.

(6) The Supreme Court is independent and adjudicates upon conflicts between state instituions, and between the state and individuals, but judges are removable by the legislative Parliament under the Aritcle 105(2) for gross misconduct.

(7) Parliament may pass legislation but the Supreme Court may delcared it unconstitutional.

(8) The plenary power of legisaiton belong to Parliament, but the executive can still issue ordinances under Article 88 and other subordinate legislation.

(9) Election are delcared by the executive, but administred by the Election Commission under Part 14.

(10) Employees of the executive are appointed by the executive itself but recrutied and recommended by the Public Service Commission under Part 13.

(11) The appointment of Supreme Court Judges in made by the constitutional Council under Article 149.

(12) Curruption and abuse of authority by public official is to be dealt with by the exeutive chief, but the commission for the investigation of abuse of authority in turn has power under Part II to check abuses by the executive.

\section{CHECK AND BALANCE OF THE SEPERATION OF POWER}

Their has been some contirovery among student of political science. Montesguieu contemplated an absolute or only a limited seperation of three powers. Other believe that he neaver thought to separate the powers completely. He rather suggested modification of the concentration of powers. "Herman Finer observes to limit the Crown to make a constitution; to build canals through which strean; to creat intermediary bodies; to check and balance probabaly dispotism and yet he did not wish to fly to the extrem of democracy."

Montesguieu political liberty had two aspects:

(1) A balanced constitution and the citizen's sense of legal security. It was for the security of political liberty its relation to the constituion that Montesguieu advocated the seperation of powers, according to which each power should be exercised by a different organ of the government and among the verious organs of government there should be a system of check and balances, so that no single organ might become all- powerfull.

(2) The main thrust of this doctrine is that if the executive and the legislative are the same person or body of person there always remians a danger of the legislature enacting oppressive laws which the executive will administer to allain its own ends. Similarly, if one body or person could exercise both executive and judicial powers in relaiton to the same matter there would be arbitrary power which would amount to complete tyranny. 


\section{CONCLUSION}

The separation of powers is certainly neither an absolute nor a predominant feature of the Nepalese Constitution. Nevertheless, it is a concept which is firmly rooted in constitutional tradition and thought. Judicial assertions of the importance of the doctrine can be explained in light of the constitutional position. The concept of separation of powers offers the judiciary a device both for the protection of the independence of the judiciary and against allegations of judicial intrusion into matters more appropriate to Parliament or the executive. The reluctance of judges to be drawn into such matters is reflected particularly strongly in relaiton to matters of the President prerogative. Accordingly, to deny the relevance of some form of separation of powers would be to misconstrue the evidence. The separation of powers is a principle respected under the constitution which exerts its influence on eahc of the fundamental institutions of the state. While the separation of powers is ill defined, and is not accorded absolute respect, it ought not to 'be lightly dismissed.

Whilist the $19^{\text {th }}$ century American Supreme Court expressed the rigid notion that each branch of government must be strictly limited to the exercirs of powers appropriate to its own department and no other, the doctrine has been more modestly interpreted by the judiciary in Nepal most recently in the case of "Ravi Raj Bhandari" (NRP, Special issue 2052: 1) Which neave Bhakta Bahadur Koirela case and Vice-president Paramanda Jha case are the less clearly showed the importance of the independent use of Judicial power and the adjudicative responsibility of the Supreme Court. This more restrictive interprelaiton of the doctrine of separation of powers is a theme which finds expression in almost all of the provisions of the constitution.

\section{WORKS CITED}

Aristotle (1962). The Politics. Sinclair, TA (trans), Penguin, Harmondsworth.

Barnett, Hilaire (2004). Constitution and Administrative Law $5^{\text {th }}$ ed., Cavendish Publishing Limited London, Sidney Portland, Oregon.

Blackstone, W(bir) (2001). Commentaries on the Law of England (1765-69). edn. Morrison, W(ed), Cavendes Publishing, London.

Bolingbroke, H. (1748). Remarks on the History of England. $3^{\text {rd }}$ ed., Francklin, London.

Jannings, I(sir) 1959). The Law and the Constitution. $5^{\text {th }}$ ed., Hidder and Stoughton, London.

Maitland, F.W. (1908). The Constitutional History of England. CUP, Cambridge.

Marshall, G. (1974). Constitutional Theory. Clarendon, Oxford.

--- (1984). Constitutional Convention. Clarendon, Oxford.

Montesguieu, C. (1989). Del' Esprit des Lois (1748). CUP, Combridge. 
Sathe, S.P. (1991). Administrative Law. $3^{\text {rd }}$ ed., N.M. Trilathi Pvt. Ltd., Bombey.

Vile, M.J.C. (1967). Constitutionalism and the Separation of Power. Clarendon, Oxford.

The Constitution of the USA.

The Constitution of India.

The Interim Constitution of Nepal 2007 (2063 B.S.). 